\title{
Effect of Different Laser Wavelengths on Periodontopathogens in Peri-Implantitis: A Review of In Vivo Studies
}

\author{
Katarzyna Świder ${ }^{1}$, Marzena Dominiak ${ }^{2}$, Kinga Grzech-Leśniak ${ }^{2}$ and Jacek Matys ${ }^{3, * D}$ \\ 1 Dental Prosthodontics Clinic, Medical University of Wroclaw, 50-425 Wroclaw, Poland \\ 2 Dental Surgery Department, Medical University of Wroclaw, 50-425 Wroclaw, Poland \\ 3 Private Dental Practice Ka-dent, Lipowa 18, 67-400 Wschowa, Poland \\ * Correspondence: jacek.matys@wp.pl
}

Received: 30 May 2019; Accepted: 26 June 2019; Published: 29 June 2019

\begin{abstract}
Nowadays, many studies are examining the effectiveness of dental lasers in the treatment of peri-implantitis; however, most of them only report periodontal parameter changes. The authors of this review tried to address the question: "What is the effect of different laser wavelengths on oral bacteria that cause peri-implantitis?" An electronic search of PubMed and Cochrane Central Register of Controlled Trials was performed. The following search terms were used: (peri-implantitis OR periimplantitis) OR/AND (microbial OR microbiologic) AND (laser OR Er:YAG OR erbium OR diode OR Nd:YAG OR neodymium-doped OR Er,Cr:YSGG OR chromium-doped). Initially, 212 studies were identified. After screening the titles and abstracts and excluding studies according to predefined inclusion criteria, seven publications were included in the review. Three studies about the effect of aPDT (antimicrobial photodynamic therapy) reported a decrease in the different bacterial strains associated with peri-implantitis, e.g., A. actinomycetemcomitans, P. gingivalis, P. intermedia, T. denticola, T. forsythia, F. nucleatum, and C. rectus. Two studies showed that the high-power diode laser may have some effect on peri-implant pathogens. Two articles about the Er:YAG laser reported a lowering in the count of oral pathogens; however, it was hard to determine if this was due to the use of the laser. aPDT has the ability to decrease the count of peri-implant pathogens, whereas Er:YAG laser application shows no significant effect on oral bacteria in the long term.
\end{abstract}

Keywords: laser; peri-implantitis; periodontopathogens; antimicrobial photodynamic therapy; decontamination; systematic review

\section{Introduction}

Endosseous implants are a widely chosen prosthetic rehabilitation treatment for missing teeth [1,2]. However, studies report that up to $56 \%$ of implant patients and even $43 \%$ of implant sites can be ailed by the peri-implant inflammatory process, known as peri-implantitis [3]. Peri-implantitis is described as inflammation of an implant supporting tissues in association with bone loss, which if left untreated, can result in the destruction of the bone [3].

The etiology of peri-implant disease is diverse. Peri-implantitis is reported to occur more frequently in nicotine smokers [4] and in patients with periodontitis [5,6]. Nonetheless, the presence of microorganisms is fundamental for the development of the infection $[7,8]$. As studies have shown, $[7,8]$ peri-implantitis harbors high levels of diverse periodontal pathogens, predominantly gram-negative species. This is also because peri-implant tissue is more complex then periodontal tissue. Peri-implant tissue is characterized by a lack of the periodontal ligament, cementum, and has altered connective tissue fibers (Figure 1). 


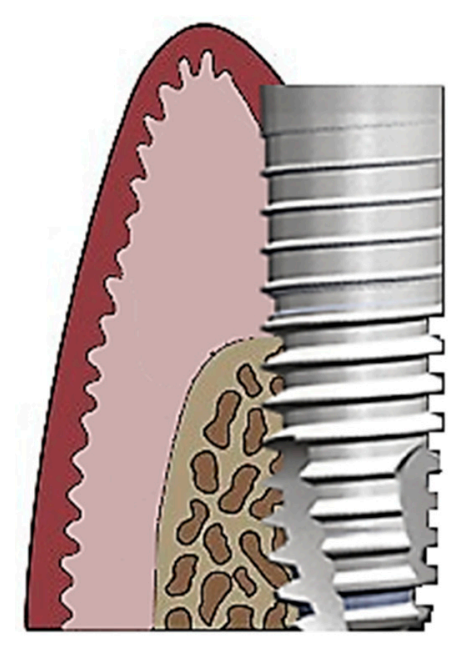

Figure 1. Schematic diagram of peri-implant tissue.

The current principles of peri-implantitis treatment are based on results established from periodontal disease therapies, and they can be divided into mechanical and/or chemical treatments [9]. Mombelli et al. [8] suggested that decontaminating the implant surface, reducing or removing periodontal pockets, re-osseointegration, and proper oral hygiene should be employed in peri-implantitis treatment. In mechanical modalities (subgingival debridement, conventional and ultrasonic scaling, carbon fiber curettes), [8,9] the main goal is the removal of biofilm from implant surfaces. However, these methods can damage the surface of implants, which can be seen in scanning electron microscopy, without effectively decontaminating the surface $[10,11]$ or producing a significant pocket depth improvement [11]. In addition, various systemic and local chemical antimicrobial agents (citric acid, chlorhexidine, hydrogen peroxide application) $[9,12]$ and antibiotics have been introduced for the treatment of peri-implantitis $[8,13,14]$. These agents complement mechanical treatment and result in more effective eradication of periodontopathogens. Nonetheless, antibiotic modalities are not free from disadvantages and can cause increases in antibiotic resistant periodontopathogens, negative systemic reactions, and immunosuppression in patients [8], whereas chemical agents can cause tissue damage or irritation $[10,13]$.

An alternative antimicrobial treatment without the complications listed above is laser-assisted therapy. Laser irradiation targets pathogens locally; thus, no systemic reactions exist. Various in vitro studies report that some laser wavelengths can not only eliminate bacteria but also bacterial toxins and lipopolysaccharides (LPS) [15,16]. In periodontal diseases, lasers can be used as a separate treatment or in addition to conventional scaling and root planning [17-19].

Nowadays, a variety of lasers are used in dental procedures as innovative therapeutic techniques that reduce bleeding, swelling, and pain [20-25]. The most used lasers are the diode and the Er:YAG laser [20]. They can be employed in both non-surgical and surgical procedures [21]. The diode laser is characterized by a hemostatic effect, the promotion of healing, and its use in sulcular debridement [21]. The Er:YAG laser has the capability to be absorbed by water molecules and therefore results in minimal thermal damage and tissue carbonization [21]. Thus, bacteria are eliminated without overheating the surrounding tissues. Additionally, some studies report that the Er:YAG laser is capable of removing plaque and calculus even from rough implant surfaces [21,26,27].

The aim of the present study was to evaluate the bactericidal potential of laser application in patients with peri-implantitis. 


\section{Materials and Methods}

\subsection{Focused Question}

A growing body of researchers is examining the clinical effectiveness of dental lasers in the treatment of peri-implantitis. However, most of the studies mainly engage with changes in periodontal parameters, less often in oral periodontal pathogens, and most them are in vitro studies. Therefore, the addressed focused question in this paper was "What is the effect of different laser wavelengths on oral bacteria that cause peri-implantitis?"

\subsection{Protocol}

The text of the review was structured in accordance with guidelines from PRISMA [28] and the Cochrane Handbook of Systematic Reviews of Interventions [29]. A detailed description of the study protocol is included in this paper (Table 1).

Table 1. Systematic Search Strategy.

\begin{tabular}{|c|c|}
\hline Focused Question & $\begin{array}{l}\text { What is the Effect of Different Laser Wavelengths on Oral Bacteria } \\
\text { that Cause Peri-Implantitis? }\end{array}$ \\
\hline \multicolumn{2}{|l|}{ Search strategy } \\
\hline Population & Patients diagnosed with peri-implantitis \\
\hline Intervention or exposure & Surgical or non-surgical laser treatment \\
\hline Comparison & Changes in oral bacterial profiles before and after treatment \\
\hline Outcome & Changed oral bacterial profiles or the number of specified bacteria \\
\hline Search combination & $\begin{array}{l}\text { (peri-implantitis OR periimplantitis) OR/AND (microbial OR } \\
\text { microbiologic) AND (laser OR Er:YAG OR erbium OR diode OR } \\
\text { Nd:YAG OR neodymium-doped OR Er,Cr:YSGG OR chromium-doped) }\end{array}$ \\
\hline Electronic database search & PubMed, Cochrane Central Register of Controlled Trials (CENTRAL) \\
\hline \multicolumn{2}{|l|}{ Selection criteria } \\
\hline Inclusion criteria & $\begin{array}{l}\text { - } \\
\text { - } \quad \text { Ptudies involving human subjects } \\
\text { - } \quad \text { Surgical or non-surgical use of dental lasers in the treatment } \\
\text { of peri-implantitis } \\
\text { - } \quad \text { Evaluated changes in specified oral bacterial profiles before and } \\
\text { after the laser treatment } \\
\text { - } \quad \text { Prospective human case series } \\
\text { - } \quad \text { Ron-randomized controlled clinical trials (NRS) }\end{array}$ \\
\hline Exclusion criteria & $\begin{array}{ll}\text { - } & \text { Animal studies } \\
\text { - } & \text { In vitro studies } \\
\text { - } & \text { Review articles } \\
\text { - } & \text { No full-text accessible } \\
\text { - } & \text { Duplicated publications }\end{array}$ \\
\hline
\end{tabular}

\subsection{Eligibility Criteria}

Studies were considered acceptable for inclusion in the review if they met the following criteria:

- Studies involving human subjects;

- Patients with peri-implantitis;

- Surgical or non-surgical use of dental lasers in the treatment of peri-implantitis; 
- Evaluated changes in specified oral bacterial profiles before and after the laser treatment;

- Prospective case series;

- Non-randomized controlled clinical trials (NRS); and

- Randomized controlled clinical trials (RCT).

The exclusion criteria the reviewers agreed upon were as follows (Table 1):

- Animal studies;

- In vitro studies;

- Review articles;

- No full-text accessible; or

- Duplicated publications.

No restrictions were applied with regard to the year of publication or to the language of the study.

\subsection{Information Sources, Search Strategy, and Study Selection}

An electronic search of PubMed and the Cochrane Central Register of Controlled Trials (CENTRAL) databases was conducted on 5 April, 2019. To review the data available on the subject of interest, the following search terms were used: (peri-implantitis OR periimplantitis) OR/AND (microbial OR microbiologic) AND (laser OR Er:YAG OR erbium OR diode OR Nd:YAG OR neodymium-doped OR Er,Cr:YSGG OR chromium-doped) (Table 1). The search was limited to human subjects and studies that adhered to other eligibility criteria. The references of all selected full-text articles and related reviews were scanned. Only papers with available or accessible full-text versions were considered. If required, an attempt was made to contact the corresponding authors of unpublished or missing data. Screening was performed by each author and the acquired data were compared.

\subsection{Data Collection Process, Data Items}

Two reviewers independently extracted data from papers that met the inclusion criteria. The following data were used: first author, title, year of publication, study design, laser type, laser parameters, and changes in specified oral bacterial profiles before and after treatment. Extracted data were entered into a standardized Excel file.

\subsection{Risk of Bias in Individual Studies}

In the initial study selection, to minimize the potential for reviewer bias, each author screened titles and abstracts independently. The level of agreement between reviewers was determined by the Cohen $k$ test. Any disagreement about the inclusion or exclusion of a study was resolved by discussion.

\subsection{Quality Assessment}

The methodological quality of each included study was evaluated independently by two blinded reviewers. The study design, implementation, and analysis were based on the following criteria: population representativeness in the treatment group (average of the population), demonstration that the outcomes were not present at the start of the treatment, comparability of the baseline and the outcome parameters, accuracy of the microbial genome evaluation technique, randomization, adequate follow-up (for outcomes to occur), and acceptable follow-up loss (complete follow-up, subjects lost to follow-up unlikely to introduce bias) (Table 2). The descriptive information about the studies was graded. The score range was from 0 to 6 points, with a higher score indicating a higher study quality. Any disagreements were resolved through discussion until reaching a consensus. 
Table 2. Quality assessment of studies.

\begin{tabular}{|c|c|c|c|c|c|c|}
\hline \multirow{2}{*}{ Criteria } & \multicolumn{6}{|c|}{ First Author } \\
\hline & $\begin{array}{c}\text { Birang et al. } \\
{[30]}\end{array}$ & $\begin{array}{c}\text { Caccianiga et al. } \\
{[31]}\end{array}$ & $\begin{array}{c}\text { Persson et al. } \\
{[32]}\end{array}$ & $\begin{array}{c}\text { Arisan et al. } \\
{[33]}\end{array}$ & $\begin{array}{c}\text { Yoshino et al. } \\
{[34]}\end{array}$ & $\begin{array}{c}\text { Bassetti et al. } \\
{[14]}\end{array}$ \\
\hline $\begin{array}{l}\text { Population } \\
\text { representativeness in the } \\
\text { treatment group (average of } \\
\text { the population) }\end{array}$ & 1 & 1 & 1 & 1 & 0 & 1 \\
\hline $\begin{array}{c}\text { Comparability of the } \\
\text { baseline and the outcome } \\
\text { parameters }\end{array}$ & 1 & 1 & 1 & 1 & 1 & 1 \\
\hline $\begin{array}{l}\text { Accuracy of the microbial } \\
\text { genome evaluation } \\
\text { technique }\end{array}$ & 1 & 1 & 0 & 0 & 0 & 1 \\
\hline Randomization & 1 & 0 & 1 & 0 & 0 & 0 \\
\hline $\begin{array}{l}\text { Adequate follow-up } \\
\text { (for outcomes to occur) }\end{array}$ & 1 & 1 & 1 & 1 & 1 & 1 \\
\hline $\begin{array}{l}\text { Acceptable follow-up loss } \\
\text { (complete follow-up, } \\
\text { subjects lost to follow-up } \\
\text { unlikely to introduce bias) }\end{array}$ & 1 & 1 & 1 & 1 & 1 & 1 \\
\hline Total & 6 & 5 & 5 & 4 & 3 & 5 \\
\hline
\end{tabular}

\subsection{Risk of Bias Across Studies}

After the scores of each study were calculated, an overall estimate of the risk of bias (low, moderate, or high) was made for each publication, as recommended in the Cochrane Handbook for Systematic Reviews of Interventions [29].

\section{Results}

\subsection{Study Selection}

Initially, 212 studies were identified. After screening of the titles and abstracts, 177 studies were excluded. Forty-eight studies were selected for thorough full-text screening, from which 41 were excluded according to predefined inclusion criteria [35-75] (Table 3). Finally, seven publications were included in the review [14,15,30-33,76] (Table 4).

Table 3. Reasons for exclusion of studies.

\begin{tabular}{ccc}
\hline First Author & Year of Publication & Reason for Exclusion \\
\hline Salaria et al. [35] & 2018 & No bacterial profile evaluated \\
\hline Karimi et al. [36] & 2016 & No bacterial profile evaluated \\
\hline Schwarz et al. [37] & 2011 & No bacterial profile evaluated \\
\hline Schwarz et al. [38] & 2017 & No bacterial profile evaluated \\
\hline Schwarz et al. [39] & 2015 & No bacterial profile evaluated \\
\hline Schwarz et al. [40] & 2004 & Systematic review \\
\hline Scarano et al. [41] & 2016 & An in vitro study \\
\hline Pommer et al. [42] & 2016 & No bacterial profile evaluated \\
\hline Norton [43] & 2017 & No bacterial profile evaluated \\
\hline Lerario et al. [44] & 2016 & No bacterial profile evaluated profile evaluated \\
\hline Hegazy et al. [45] & 2016 & No bacterial profile evaluated \\
\hline John et al. [46] & 2017 & No bacterial profile evaluated \\
\hline Valente et al. [47] & 2018 & No bacterial profile evaluated \\
\hline Romeo et al. [48] & 2016 &
\end{tabular}


Table 3. Cont.

\begin{tabular}{|c|c|c|}
\hline First Author & Year of Publication & Reason for Exclusion \\
\hline Al Amri et al. [49] & 2016 & No bacterial profile evaluated \\
\hline Abduljabbar et al. [50] & 2017 & No bacterial profile evaluated \\
\hline Larsen et al. [51] & 2017 & An in vitro study \\
\hline Nicholson et al. [52] & 2017 & No bacterial profile evaluated \\
\hline Spadari et al. [53] & 2010 & No full-text accessible \\
\hline Bombeccari et al. [54] & 2013 & No bacterial profile evaluated \\
\hline Chambrone et al. [55] & 2018 & Systematic review \\
\hline Esposito et al. [56] & 2008 & Systematic review \\
\hline Ashnagar et al. [57] & 2014 & Systematic review \\
\hline Papadopoulos et al. [58] & 2015 & No bacterial profile evaluated \\
\hline Renvert et al. [59] & 2008 & Systematic review \\
\hline Renvert et al. [60] & 2011 & No bacterial profile evaluated \\
\hline Yan et al. [61] & 2015 & Systematic review \\
\hline Natto et al. [62] & 2015 & Systematic review \\
\hline Smeets et al. [63] & 2014 & Systematic review \\
\hline Kotsakis et al. [64] & 2014 & Systematic review \\
\hline Figuero et al. [65] & 2000 & Systematic review \\
\hline Suárez-López Del Amo et al. [66] & 2016 & Systematic review \\
\hline Alshehri et al. [67] & 2016 & Systematic review \\
\hline Ghanem et al. [68] & 2016 & Systematic review \\
\hline Mizutani et al. [69] & 2000 & Systematic review \\
\hline Mahato et al. [70] & 2016 & Systematic review \\
\hline Al Habashneh et al. [71] & 2015 & Systematic review \\
\hline Subramani et al. [72] & 2012 & Systematic review \\
\hline Rajesh et al. [73] & 2011 & Systematic review \\
\hline Gonçalves at al. [74] & 2010 & Systematic review \\
\hline Kotsovilis at al. [75] & 2008 & Systematic review \\
\hline
\end{tabular}

Table 4. General characteristics of the included studies.

\begin{tabular}{|c|c|c|c|c|}
\hline First Author & $\begin{array}{l}\text { Study Design } \\
\text { (No. of Subjects) }\end{array}$ & Laser Type & Laser Parameters & Evaluated Bacteria \\
\hline Birang et al. [30] & RCT & diode & $\begin{array}{c}810 \mathrm{~nm}, 300 \mathrm{~mW}, 30 \mathrm{~s} \text { per site, } \\
\text { large-area handpiece } \\
\text { (transgingival) or bulb fiber } \\
\text { (intra-pocket) or bare fiber } \\
\text { (granulation tissues), } \\
\text { irradiation repeated after } \\
2 \text { weeks }\end{array}$ & $\begin{array}{l}\text { Aggregatibacter } \\
\text { actinomycetemcomitans, } \\
\text { Porphyromonas gingivalis, } \\
\text { Prevotella intermedia, } \\
\text { Treponema denticola, } \\
\text { Tannerella forsythia }\end{array}$ \\
\hline $\begin{array}{c}\text { Caccianiga et al. } \\
\text { [31] }\end{array}$ & $\begin{array}{l}\text { prospective case } \\
\text { series }\end{array}$ & diode (aPDT) & $\begin{array}{l}2.5 \mathrm{~W}, 0.5 \mathrm{~W} \text { (mean power), } \\
10 \mathrm{kHz}, \mathrm{T} \text {-on } 20 \text { us, T-off } 80 \mathrm{us,} \\
60 \mathrm{~s} \text { per site, } 400 \text { micron fiber, } \\
\text { periodontal and peri-implant } \\
\text { pocket site, irradiation } \\
\text { repeated after } 15 \text { days and } \\
\text { then for the next } 3 \text { months } \\
\text { every } 20 \text { days, } \\
3 \% \text { hydrogen peroxide }\end{array}$ & $\begin{array}{l}\text { Aggregatibacter } \\
\text { actinomycetemcomitans, } \\
\text { Porphyromonas gingivalis, } \\
\text { Treponema denticola, } \\
\text { Tannerella forsythia, } \\
\text { Fusobacterium nucleatum, } \\
\text { Campylobacter rectus, } \\
\text { Eikenella corrodens }\end{array}$ \\
\hline
\end{tabular}


Table 4. Cont.

\begin{tabular}{|c|c|c|c|c|}
\hline First Author & $\begin{array}{c}\text { Study Design } \\
\text { (No. of Subjects) }\end{array}$ & Laser Type & Laser Parameters & Evaluated Bacteria \\
\hline Persson et al. [32] & $\mathrm{RCT}$ & Er:YAG & $\begin{array}{c}100 \mathrm{~mJ} / \text { pulse, } 10 \mathrm{~Hz}(12.7 \mathrm{~J} / \mathrm{cm}) \\
\text { cone-shaped sapphire tip, } \\
\text { parallel mode, pocket site }\end{array}$ & $\begin{array}{l}74 \text { specimens (Campylobacter } \\
\text { showae, Capnocytophaga } \\
\text { ochracea, P. melaninogenica, } \\
\text { S. anaerobius, S. hae- molyticus, } \\
\text { S.intermedius, and S. mutans) }\end{array}$ \\
\hline Arisan et al. [33] & RCT & diode & $\begin{array}{c}810 \mathrm{~nm} \text { (energy density, } \\
3 \mathrm{~J} / \mathrm{cm}^{2} ; \text { power density, } \\
400 \mathrm{~mW} / \mathrm{cm}^{2} ; \text { energy } 1.5 \mathrm{~J} ; \\
\text { spot diameter, } 1 \mathrm{~mm}), 60 \mathrm{~s} \text { per } \\
\text { site, pulsed mode, power level } \\
\text { of } 1 \mathrm{~W}, 400 \text { um optical fiber tip, } \\
\text { peri-implant pocket area }\end{array}$ & $\begin{array}{c}20 \text { specimen (Tannerella } \\
\text { forsythia, Treponema denticola, } \\
\text { Porphyromonas gingivalis, } \\
\text { Campylobacter rectus, } \\
\text { Prevotella intermedia, } \\
\text { Peptostreptococcus micros, } \\
\text { Fusobacterium nucleatum, } \\
\text { Eubacterium nodatum, } \\
\text { Streptococcus constellatus } \\
\text { group, Campylobacter gracilis, } \\
\text { Prevotella nigrescens) }\end{array}$ \\
\hline Yoshino et al. [34] & $\begin{array}{l}\text { prospective case } \\
\text { series }\end{array}$ & Er:YAG & $\begin{array}{l}150 \mathrm{~mJ} \text { (10 ps), } 40 \mathrm{~mJ} \text { (10 pps), } \\
70 \mathrm{~mJ}(25 \mathrm{pps}), \text { straight tip } \\
\text { (bone area), side tip (implant } \\
\text { area), straight-and-side } \\
\text { (gingival sulcus area) }\end{array}$ & $\begin{array}{l}\text { Aggregatibacter } \\
\text { actinomycetemcomitans, } \\
\text { Porphyromonas gingivalis, } \\
\text { Prevotella intermedia, } \\
\text { Treponema denticola, } \\
\text { Tannerella forsythia }\end{array}$ \\
\hline Bassetti et al. [14] & RCT & $\begin{array}{l}\text { diode } \\
\text { (aPDT) }\end{array}$ & $\begin{array}{c}660 \mathrm{~nm}, 100 \mathrm{~mW}, 10 \mathrm{~s} \text { per site, } \\
\text { peri-implant pocket area, } \\
\text { irradiation repeated after } \\
1 \text { week } \\
\text { toluidine blue O dye (TBO) }\end{array}$ & $\begin{array}{c}\text { Aggregatibacter } \\
\text { actinomycetemcomitans, } \\
\text { Porphyromonas gingivalis, } \\
\text { Prevotella intermedia, } \\
\text { Treponema denticola, } \\
\text { Tannerella forsythia, } \\
\text { Fusobacterium nucleatum, } \\
\text { Campylobacter rectus, } \\
\text { Capnocytophaga gingivalis, } \\
\text { Parvimonas micra, } \\
\text { Eubacterium nodatum, } \\
\text { Eikenella corrodens }\end{array}$ \\
\hline $\begin{array}{c}\text { Dörtbudak et al. } \\
\text { [76] }\end{array}$ & $\begin{array}{l}\text { prospective case } \\
\text { series }\end{array}$ & $\begin{array}{l}\text { diode } \\
\text { (aPDT) }\end{array}$ & $\begin{array}{c}690 \mathrm{~nm}, 60 \mathrm{~s} \text { per site, implant } \\
\text { and per-implant pocket site } \\
\text { TBO }\end{array}$ & $\begin{array}{c}\text { Aggregatibacter } \\
\text { actinomycetemcomitans, } \\
\text { Porphyromonas gingivalis, } \\
\text { Prevotella intermedia }\end{array}$ \\
\hline
\end{tabular}

\subsection{General Characteristics of the Included Studies}

Seven articles reporting four randomized controlled trials $[14,30,32,33]$ and three prospective case series $[31,34,76]$ were included in this review (Table 4). Two studies evaluated the photothermal effect of the diode laser [30,77], two evaluated the Er:YAG laser [32,34] and three evaluated aPDT (antimicrobial photodynamic therapy) $[14,31,76]$ on peri-implant pathogens. Various bacterial profiles were assessed in the articles. Also, the follow-up period differentiated from right after the therapy to up to 2 years (Table 5). 
Table 5. Follow-up and microbial test assessment of the included studies.

\begin{tabular}{|c|c|c|c|}
\hline First author & Subject Groups & Microbial Genome Evaluation & Follow-Up \\
\hline Birang et al. [30] & $\begin{array}{c}\text { Control (mechanical } \\
\text { debridement + diode laser), } \\
\text { test (mechanical debridement } \\
\text { + diode laser EmunDo) }\end{array}$ & $\begin{array}{l}\text { real-time polymerase chain } \\
\text { reaction (RT-PCR) technique }\end{array}$ & 3 months \\
\hline Caccianiga et al. [31] & $\begin{array}{l}\text { Only one group (aPDT } \\
\text { Oxylaser) }\end{array}$ & $\begin{array}{l}\text { real-time polymerase chain } \\
\text { reaction (RT-PCR) technique }\end{array}$ & 6 months \\
\hline Persson et al. [32] & $\begin{array}{l}\text { Test } 1 \text { (Er:YAG laser), test } 2 \\
\text { (air-abrasive device) }\end{array}$ & DNA-DNA hybridization method & 6 months \\
\hline Arisan et al. [33] & $\begin{array}{c}\text { Control (mechanical } \\
\text { debridement), test (mechanical } \\
\text { debridement + diode laser) }\end{array}$ & $\begin{array}{l}\text { polymerase chain reaction } \\
\text { (PCR) technique }\end{array}$ & 6 months \\
\hline Yoshino et al. [34] & Only one group (Er:YAG laser) & $\begin{array}{l}\text { polymerase chain reaction (PCR) } \\
\text { technique }\end{array}$ & 2 years \\
\hline Bassetti et al. [14] & $\begin{array}{l}\text { Control (mechanical } \\
\text { debridement), test (mechanical } \\
\text { debridement }+ \text { aPDT) }\end{array}$ & $\begin{array}{l}\text { real-time polymerase chain } \\
\text { reaction (RT-PCR) technique }\end{array}$ & 12 months \\
\hline Dörtbudak et al. [76] & $\begin{array}{c}\text { Control (no treatment), } \\
\text { test } 1 \text { (dye), } \\
\text { test } 2 \text { (dye + laser-aPDT) }\end{array}$ & $\begin{array}{l}\text { gram staining, colony morphology, } \\
\text { positive catalase reaction, BANA, } \\
\text { hydrolytic activity, a-glucosidase } \\
\text { activity, B-galactosidase, esculin } \\
\text { hydrolysis and indole test }\end{array}$ & $\begin{array}{l}\text { Right after the } \\
\text { therapy }\end{array}$ \\
\hline
\end{tabular}

\subsection{Results of Individual Studies}

In the study by Dörtbudak et al. [76], the authors reported that the aPDT reduced the bacterial counts of A. actinomycetemcomitans (A.a.), P. gingivalis (P.g.), and P. intermedia (P.i.). Also, Bassetti et al. [14] found that mechanical debridement and additional aPDT (TBO dye) seem to be able to decrease the total bacterial count, but the difference was reported to be of no significance. Caccianiga et al. [31] reported a medium decrease of most periodontal pathogens, including A.a., P.g., T. denticola (T.d.), T. forsythia (T.f.), F. nucleatum (F.n.), and C. rectus (C.r.) but excluding E. corrodens (E.c.), that increased in count after aPDT ( $3 \%$ hydrogen peroxide). Moreover, in the research by Birang et al. [30], diode laser irradiation of the implant site decreased the counts of P.g. and A.a. The authors also reported significantly decreased A.a., T.f., and P.g. in the test group that used a photosensitizer. These findings correspond to the study by Arisan et al. [33] who concluded that diode laser application reduced the total bacterial count, but the difference was stated to be of no significance.

Yoshino et al. [34], in their study on the Er:YAG laser, reported eradication of oral pathogens. Additionally, Persson et al. [32] showed lower bacterial counts in the laser-treated group for F. nucleatum naviforme and F. nucleatum nucleatum at 1 month after treatment and in comparison to baseline levels. However, at 3 months and at the final examination at 6 months, counts of bacteria increased (Table 6).

Table 6. Results of individual studies.

\begin{tabular}{|c|c|c|c|c|c|c|c|c|}
\hline \multirow{2}{*}{$\begin{array}{l}\text { Periodontal } \\
\text { Pathogens }\end{array}$} & \multirow{2}{*}{ Follow-Up } & \multicolumn{7}{|c|}{ First Author } \\
\hline & & $\begin{array}{l}\text { Birang } \\
\text { et al. [30] }\end{array}$ & $\begin{array}{l}\text { Caccianiga } \\
\text { et al. [31] }\end{array}$ & $\begin{array}{l}\text { Persson } \\
\text { et al. [32] }\end{array}$ & $\begin{array}{l}\text { Arisan } \\
\text { et al. [33] }\end{array}$ & $\begin{array}{l}\text { Yoshino } \\
\text { et al. [34] }\end{array}$ & $\begin{array}{l}\text { Bassetti } \\
\text { et al. [14] }\end{array}$ & $\begin{array}{l}\text { Dörtbudak } \\
\text { et al. [76] }\end{array}$ \\
\hline \multirow{4}{*}{$\begin{array}{c}\text { Aggregatibacter } \\
\text { actinomycetemcomitans }\end{array}$} & 1 month & ne & ne & $\mathrm{H}$ & $\mathrm{L}$ & ne & ne & ne \\
\hline & 6 months & ne & $L^{*}$ & $\mathrm{H}$ & ne & ne & $L^{*}$ & ne \\
\hline & 1 year & ne & ne & ne & ne & ne & $L^{*}$ & ne \\
\hline & 2 years & ne & ne & ne & ne & $\mathrm{L}$ & ne & ne \\
\hline
\end{tabular}


Table 6. Cont.

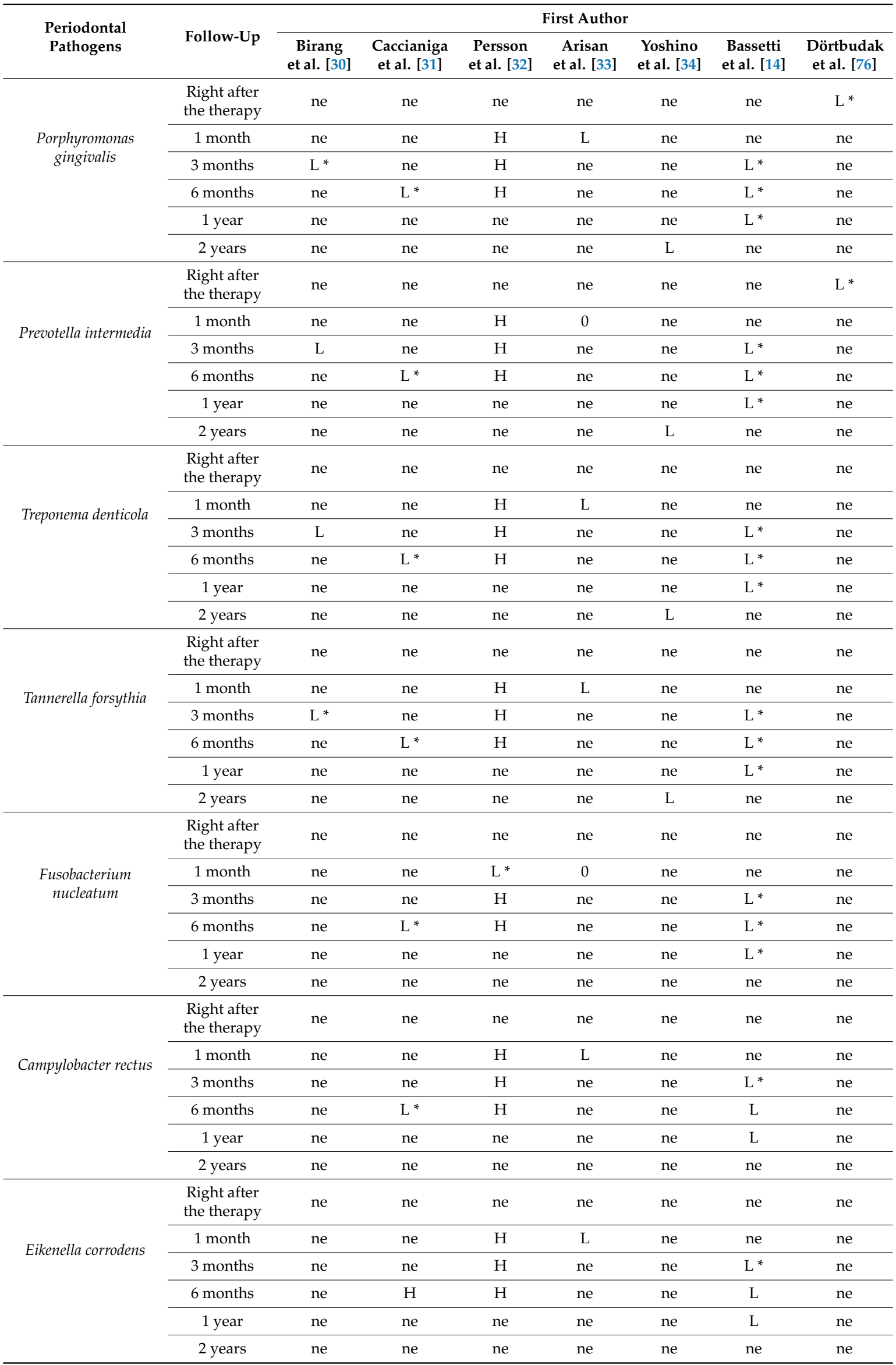

$\mathrm{L}=$ lower than baseline; $\mathrm{H}=$ higher than baseline; ne $=$ not evaluated; ${ }^{*}=$ significant difference; $0=$ no changes. 


\subsection{Synthesis of Results}

The studies included in the review varied in terms of the following features: laser parameters, evaluated periodontal pathogens (Table 4), follow-up period, and microbial genome evaluation (Table 5). Collected features were analyzed and put into an Excel file (Table 6).

The authors of the review paid special attention only to significant microbiological changes in the bacterial counts of each study at each follow-up period. It was impossible to analyze each bacterial count since some studies did not include that information. Therefore, the authors decided to focus on the changes (lower, higher) in relation to the baseline, accentuating significant variables (Table 6).

\subsection{Risk of Bias Across Studies}

The articles by Persson et al. [32] and Birang et al. [30] reported blinding of the patients and examiner and random allocation of the patients by a computer program; therefore, the studies were considered to have a low risk of bias. Another two were RCTs and had some above information missing and were reported to be at a medium risk of bias $[14,33]$. Since three studies were prospective case series $[31,34,76]$, they were considered to be at a high risk of bias (Table 7).

Table 7. Risk of bias across studies.

\begin{tabular}{|c|c|c|c|c|}
\hline First Author & Randomization & $\begin{array}{l}\text { Blinding } \\
\text { Examiner }\end{array}$ & $\begin{array}{l}\text { Blinding } \\
\text { Patients }\end{array}$ & Statistical Methods \\
\hline Birang et al. [30] & Program software & yes & yes & $\begin{array}{l}\text { SPSS 20, Kruskal-Wallis test, } \\
\text { Friedman's and Wilcoxon } \\
\text { tests, Wilcoxon test }\end{array}$ \\
\hline \multicolumn{5}{|l|}{ Caccianiga et al. [31] } \\
\hline Persson et al. [32] & Program software & yes & yes & $\begin{array}{c}\text { Kruskal-Wallis test, } \\
\text { Mann-Whitney U tests, } \\
\text { Wilcoxon test, Spearman } \\
\text { rank correlation, x2 analysis }\end{array}$ \\
\hline Arisan et al. [33] & Not described & Not described & Not described & $\begin{array}{c}\text { D'Agastino Pearson } \\
\text { Omnibus Normality test, } \\
\text { Sidak's test, Fisher's exact } \\
\text { test, McNemar Test }\end{array}$ \\
\hline \multicolumn{5}{|l|}{ Yoshino et al. [34] } \\
\hline Bassetti et al. [14] & Not described & yes & Not described & $\begin{array}{c}\text { SD, Student's t-test, } \\
\text { Wilcoxon test, Chi-square } \\
\text { test, Mann-Whitney U-test, } \\
\text { Fisher's exact test }\end{array}$ \\
\hline Dörtbudak et al. [76] & & & & Tukey Student test \\
\hline
\end{tabular}

\section{Discussion}

The findings of this review show that laser application in peri-implantitis may decontaminate the implant surface and eradicate periodontal pathogens in some cases. The seven papers included to this review can be divided according to the laser treatment modalities used. Two studies evaluated the photothermal effect of the diode laser [30,33], two evaluated the Er:YAG laser [32,34] and three evaluated antimicrobial photodynamic therapy $[14,31,76]$ on the eradication of peri-implant pathogens.

In the studies of Arisan et al. [33] and Birang et al. [30], the authors used high-power diode lasers to eradicate the bacterial biofilm from the implant titanium surface due to the photothermal effect. The use of high-power diode lasers on tissues is inextricably linked with the increase of their temperature, which, in turn, causes several changes in the structure of tissues through protein denaturation, microbial elimination, water evaporation, coagulation, and even melting $[17,18]$. The first changes in the structure of the oral soft tissue begin when its temperature was increased to $42{ }^{\circ} \mathrm{C}$ $\left(\Delta \mathrm{T}=5^{\circ} \mathrm{C}\right)$, and then changes occurred within the cell membranes [78]. In the study by Arisan et al. [33], mechanical therapy and additional diode laser application decreased the total bacterial count on the 
affected peri-implant zone. The author measured insignificant differences in the results of decreasing of A.a., P.g., T.d., T.f., C.r., E.c. species after a 1 month follow-up period in contrast to the control group. In turn, the research by Birang et al. [30] showed that diode laser $(810 \mathrm{~nm}, 300 \mathrm{~mW}, 30 \mathrm{~s})$ irradiation of the implant site decreased the count of P.g., and differences in A.a. reached the significance threshold. Moreover, the authors reported significant decreases in the A.a., T.f., and P.g. strains after 3 months in the test group that additionally used infracyanine green. However, there were no significant differences between the laser modalities (with or without infracyanine green).

Antimicrobial photodynamic therapy was applied for peri-implantitis treatment in the studies of Dörtbudak et al. [76], Bassetti et al. [14], and Caccianiga et al. [31]. During this process, a combination of nontoxic photosensitizing dyes with appropriate wavelengths of light led to the production of reactive oxygen species. The reactive oxygen species produced with aPDT had high killing potential against bacteria, fungi, and viruses [33]. In the study by Dörtbudak et al. [76], the authors evaluated the culture counts for A. actinomycetemcomitans, P. gingivalis, and P. intermedia. It was found that aPDT reduced the bacterial counts measured immediately after therapy by 2 logs. These findings correspond to Caccianiga et al. [31], who reported a medium decrease in most periodontal pathogens (A.a., P.g., T.d., T.f., F.n., C.r.) excluding E.c. which increased in count after a 6 month follow-up period. Also, in the study by Bassetti et al. [14], mechanical debridement and additional aPDT application reduced the total bacterial counts on affected peri-implant sulcus. The counts of P.g. and T.f. decreased significantly from baseline to 6 months following aPDT and after 12 months in the local antibiotics group. The authors concluded that aPDT seems to be an alternative approach to local antibiotics for non-surgical therapy of peri-implantitis.

Two articles assessed the influence of the Er:YAG laser on oral cavity microbes associated with peri-implantitis [32,34]. The Er:YAG laser has the highest absorption coefficient in water, which is the main component of vital organisms. This physical property influences the ability of the wavelength to damage of the water-rich cells and constitutes the significant killing potential of this laser. [79] Yoshino et al. [34], in their study, reported on the eradication of oral pathogens; however, the laser application was preceded by a systemic antibiotic protocol (amoxycilin, metronidazol); therefore, it is impossible to conclude the real reason for the bacteria count decrease. In turn, Persson et al. [32] showed lower bacterial counts in the laser-treated group for F. nucleatum naviforme and F. nucleatum nucleatum at 1 month after treatment and in comparison to baseline levels. However, at 3 months and at the final examination at 6 months, the counts of bacteria increased. It should be highlighted that the study conducted by Person et al. [32] was a non-surgical approach to the treatment of peri-implantitis. The threads and rough surfaces of implants are complicated to manage by non-flap methods; thus, this could explain the lack of reduction in the total bacterial amount in the study.

More studies with bigger populations of patients are needed to determine the use of dental lasers in bacteria decontamination.

\section{Conclusions}

It can be concluded that a high-power diode laser may have some effect on peri-implant pathogens causing peri-implantitis, whereas Er:YAG laser application shows no significant effect on oral bacteria in the long term.

aPDT has the ability to reduce the total count of the different bacterial strains associated with peri-implantitis, e.g., A. actinomycetemcomitans, P. gingivalis, P. intermedia, T. denticola, T. forsythia, F. nucleatum, and C. rectus.

Author Contributions: Conceptualization, K.Ś. and J.M.; Methodology, K.Ś.; Software, J.M.; Validation, J.M.; Formal Analysis, K.S.., J.M., M.D. and K.G.-L.; Investigation, K.Ś. and J.M.; Resources, K.Ś. and J.M.; Data Curation, K.S. and J.M.; Writing—Original Draft Preparation, K.Ś. and J.M.; Writing-Review and Editing, K.Ś., J.M.; M.D., K.G.-L. Visualization, K.Ś.; Supervision, J.M.; Project Administration, J.M., M.D., K.G.-L.

Funding: This research did not receive any specific grant from funding agencies in the public, commercial, or not-for-profit sectors. 
Conflicts of Interest: The authors declare no conflict of interest.

\section{References}

1. Matys, J.; Dominiak, M. Assessment of Pain When Uncovering Implants with Er:YAG Laser or Scalpel for Second Stage Surgery. Adv. Clin. Exp. Med. 2016, 25, 1179-1184. [PubMed]

2. Matys, J.; Świder, K.; Flieger, R.; Dominiak, M. Assessment of the primary stability of root analog zirconia implants designed using cone beam computed tomography software by means of the Periotest ${ }^{\circledR}$ device: An ex vivo study. A preliminary report. Adv. Clin. Exp. Med. 2017, 26, 803-809. [CrossRef] [PubMed]

3. Matys, J.; Botzenhart, U.; Gedrange, T.; Dominiak, M. Thermodynamic effects after Diode and Er:YAG laser irradiation of grade IV and V titanium implants placed in bone-an ex vivo study. Preliminary report. Biomed. Tech. (Berl). 2016, 61, 499-507. [CrossRef] [PubMed]

4. Aglietta, M.; Siciliano, V.I.; Rasperini, G.; Cafiero, C.; Lang, N.P.; Salvi, G.E. A 10-year retrospective analysis of marginal bone-level changes around implants in periodontally healthy and periodontally compromised tobacco smokers. Clin. Oral Implant. Res. 2011, 22, 47-53. [CrossRef] [PubMed]

5. Roccuzzo, M.; De Angelis, N.; Bonino, L.; Aglietta, M. Ten-year results of a three-arm prospective cohort study on implants in periodontally compromised patients. Part 1: Implant loss and radiographic bone loss. Clin. Oral Implant. Res. 2010, 21, 490-496. [CrossRef] [PubMed]

6. Roccuzzo, M.; Bonino, F.; Aglietta, M.; Dalmasso, P. Ten-year results of a three arms prospective cohort study on implants in periodontally compromised patients. Part 2: Clinical results. Clin. Oral Implant. Res. 2012, 23, 389-395. [CrossRef] [PubMed]

7. Mombelli, A.; Lang, N.P. The diagnosis and treatment of peri-implantitis. Periodontol 2000, 17, 63-76. [CrossRef]

8. Yeh, H.C.; Lu, J.J.; Chang, S.C.; Ge, M.C. Identification of microbiota in peri-implantitis pockets by matrix-assisted laser desorption/ionization time-of-flight mass spectrometry. Sci. Rep. 2019, 9, 774. [CrossRef]

9. Lang, N.P.; Wilson, T.G.; Corbet, E.F. Biological complica- tions with dental implants: Their prevention, diagnosis and treatment. Clin. Oral Implant. Res. 2000, 11, 146-155. [CrossRef]

10. Dennison, D.K.; Huerzeler, M.B.; Quinones, C.; Caffesse, R.G. Contaminated implant surfaces: An in vitro comparison of implant surface coating and treatment modalities for decontamination. J. Periodontol. 1994, 65, 942-948. [CrossRef]

11. Augthun, M.; Tinschert, J.; Huber, A. In vitro studies on the effect of cleaning methods on different implant surfaces. J. Periodontol. 1998, 69, 857-864. [CrossRef] [PubMed]

12. Schar, D.; Ramseier, C.A.; Eick, S.; Arweiler, N.B.; Sculean, A.; Salvi, G.E. Anti-infective therapy of peri-implantitis with adjunctive local drug delivery or photodynamic therapy: Six-month outcomes of a prospective randomized clinical trial. Clin. Oral Implant. Res. 2013, 24, 104-110. [CrossRef] [PubMed]

13. Gosau, M.; Hahnel, S.; Schwarz, F.; Gerlach, T.; Reichert, T.E.; Bürgers, R. Effect of six different peri-implantitis disinfection methods on in vivo human oral biofilm. Clin. Oral Implant. Res. 2010, 21, 866-872.

14. Bassetti, M.; Schär, D.; Wicki, B.; Eick, S.; Ramseier, C.A.; Arweiler, N.B.; Sculean, A.; Salvi, G.E. Anti-infective therapy of peri-implantitis with adjunctive local drug delivery or photodynamic therapy: 12-month outcomes of a randomized controlled clinical trial. Clin. Oral Implant. Res. 2014, 25, 279-287. [CrossRef] [PubMed]

15. Pick, R.M.; Pecaro, B.C.; Silberman, C.J. The laser gingivetomy. The use of the CO2 laser for the removal of phnytoin hyperplasia. J. Periodontol. 1985, 56, 492-496. [CrossRef] [PubMed]

16. Folwaczny, M.; Aggstaller, H.; Mehl, A.; Hickel, R. Removal of bacterial endotoxin from root surface with Er:YAG laser. Am. J. Dent. 2003, 16, 3-5. [PubMed]

17. Grzech-Leśniak, K.; Sculean, A.; Gašpirc, B. Laser reduction of specific microorganisms in the periodontal pocket using Er:YAG and Nd:YAG lasers: A randomized controlled clinical study. Lasers Med. Sci. 2018, 33, 1461-1470. [CrossRef]

18. Grzech-Leśniak, K. Making use of lasers in periodontal treatment: A new gold standard? Photomed. Laser Surg. 2017, 35, 513-514. [CrossRef]

19. Vohra, F.; Al-Rifaiy, M.Q.; Lillywhite, G.; Abu Hassan, M.I.; Javed, F. Efficacy of mechanical debridement with adjunct antimicrobial photodynamic therapy for the management of peri-implant diseases: A systematic review. Photochem. Photobiol. Sci. 2014, 13, 1160-1168. [CrossRef] 
20. Grzech-Leśniak, K.; Matys, J.; Jurczyszyn, K.; Ziółkowski, P.; Dominiak, M.; Brugnera Junior, A., Jr.; Romeo, U. Histological and Thermometric Examination of Soft Tissue De-Epithelialization Using Digitally Controlled Er:YAG Laser Handpiece: An Ex Vivo Study. Photomed. Laser Surg. 2018, 36, 313-319. [CrossRef]

21. Coluzzi, D.J.; Goldstein, A.J. Lasers in dentistry. An overview. Dent. Today. 2004, 23, 120-127. [CrossRef] [PubMed]

22. Matys, J.; Dominiak, M.; Flieger, R. Energy and power density: A key factor in lasers studies. J. Clin Diag Res. 2015, 9, ZL01. [CrossRef] [PubMed]

23. Matys, J.; Flieger, R.; Dominiak, M. Assessment of Temperature Rise and Time of Alveolar Ridge Splitting by Means of Er:YAG Laser, Piezosurgery, and Surgical Saw: An Ex Vivo Study. Biomed. Res Int. 2016, 2016. [CrossRef] [PubMed]

24. Matys, J.; Flieger, R.; Tenore, G.; Grzech-Leśniak, K.; Romeo, U.; Dominiak, M. Er:YAG laser, piezosurgery, and surgical drill for bone decortication during orthodontic mini-implant insertion: Primary stability analysis—an animal study. Lasers Med. Sci. 2018, 33, 489-495. [CrossRef] [PubMed]

25. Matys, J.; Swider, K.; Flieger, R. Laser instant implant impression method: A case presentation. Dent. Med. Probl. 2017, 54, 101-106. [CrossRef]

26. Schwarz, F.; Rothamel, D.; Sculean, A.; Georg, T.; Scherbaum, W.; Becker, J. Effects of an Er:YAG laser and the Vector ultrasonic system on the biocompatibility of titanium implants in cultures of human osteoblast-like cells. Clin. Oral Implant. Res. 2003, 14, 784-792. [CrossRef]

27. Friedmann, A.; Antic, L.; Bernimoulin, J.P.; Purucker, P. In vitro attachment of osteoblasts on contaminated rough titanium surfaces treated by Er:YAG laser. J. Biomed. Mater. Res. A. 2006, 79, 53-60. [CrossRef] [PubMed]

28. Moher, D.; Liberati, A.; Tetzlaff, J.; Altman, D.G.; PRISMA, Group. Pre-ferred reportingitems for systematic reviews andmeta-analyses: The PRISMA statement. J. Clin. Epidemiol. 2009, 62, 1006-1012. [CrossRef]

29. Higgins, J.P.T.; Green, S. Cochrane Handbook for Systematic Reviews of Interventions Version 5.1.0. The Cochrane Collaboration, 2011. Available online: http://handbook.cochrane.org (accessed on 2 April 2019).

30. Birang, E.; Talebi Ardekani, M.R.; Rajabzadeh, M.; Sarmadi, G.; Birang, R.; Gutknecht, N. Evaluation of Effectiveness of Photodynamic Therapy With Low-level Diode Laser in Nonsurgical Treatment of Peri-implantitis. J. Lasers Med. Sci. 2017, 8, 136-142. [CrossRef]

31. Caccianiga, G.; Rey, G.; Baldoni, M.; Paiusco, A. Clinical, Radiographic and Microbiological Evaluation of High Level Laser Therapy, a New Photodynamic Therapy Protocol, in Peri-Implantitis Treatment; a Pilot Experience. Biomed. Res. Int. 2016, 2016, 6321906. [CrossRef]

32. Persson, G.R.; Roos-Jansåker, A.M.; Lindahl, C.; Renvert, S. Microbiologic results after non-surgical erbium-doped:yttrium, aluminum, and garnet laser or air-abrasive treatment of peri-implantitis: A randomized clinical trial. J. Periodontol. 2011, 82, 1267-1278. [CrossRef] [PubMed]

33. Arısan, V.; Karabuda, Z.C.; Arıcı, S.V.; Topçuoğlu, N.; Külekçi, G. A randomized clinical trial of an adjunct diode laser application for the nonsurgical treatment of peri-implantitis. Photomed Laser Surg. 2015, 33, 547-554. [CrossRef] [PubMed]

34. Yoshino, T.; Yamamoto, A.; Ono, Y. Innovative regeneration technology to solve peri-implantitis by Er:YAG laser based on the microbiologic diagnosis: A case series. Int. J. Periodontics Restor. Dent. 2015, 35, 67-73. [CrossRef] [PubMed]

35. Salaria, S.K.; Sharma, I.; Brar, N.K.; Kaur, S. Diode Laser and Periodontal Regeneration-Assisted Management of Implant Complications in Anterior Maxilla. Contemp. Clin. Dent. 2018, 9, 114-119. [PubMed]

36. Karimi, M.R.; Hasani, A.; Khosroshahian, S. Efficacy of Antimicrobial Photodynamic Therapy as an Adjunctive to Mechanical Debridement in the Treatment of Peri-implant Diseases: A Randomized Controlled Clinical Trial. J. Lasers Med. Sci. 2016, 7, 139-145. [CrossRef] [PubMed]

37. Schwarz, F.; Sahm, N.; Iglhaut, G.; Becker, J. Impact of the method of surface debridement and decontamination on the clinical outcome following combined surgical therapy of peri-implantitis: A randomized controlled clinical study. J. Clin. Periodontol. 2011, 38, 276-284. [CrossRef] [PubMed]

38. Schwarz, F.; John, G.; Schmucker, A.; Sahm, N.; Becker, J. Combined surgical therapy of advanced peri-implantitis evaluating two methods of surface decontamination: A 7-year follow-up observation. J. Clin. Periodontol. 2017, 44, 337-342. [CrossRef] [PubMed] 
39. Schwarz, F.; John, G.; Hegewald, A.; Becker, J. Non-surgical treatment of peri-implant mucositis and peri-implantitis at zirconia implants: A prospective case series. J. Clin. Periodontol. 2015, 42, 783-788. [CrossRef]

40. Schwarz, F.; Bieling, K.; Sculean, A.; Herten, M.; Becker, J. Treatment of periimplantitis with laser or ultrasound. A review of the literature. Schweiz Mon. Zahnmed. 2004, 114, 1228-1235.

41. Scarano, A.; Nardi, G.; Murmura, G.; Rapani, M.; Mortellaro, C. Evaluation of the Removal Bacteria on Failed Titanium Implants After Irradiation With Erbium-Doped Yttrium Aluminium Garnet Laser. J. Craniofac. Surg. 2016, 27, 1202-1204. [CrossRef] [PubMed]

42. Pommer, B.; Haas, R.; Mailath-Pokorny, G.; Fürhauser, R.; Watzek, G.; Busenlechner, D.; Müller-Kern, M.; Kloodt, C. Periimplantitis Treatment: Long-Term Comparison of Laser Decontamination and Implantoplasty Surgery. Implant. Dent. 2016, 25, 646-649. [CrossRef] [PubMed]

43. Norton, M.R. Efficacy of Er:YAG Laser in the Decontamination of Peri-implant Disease: A One-Year Prospective Closed Cohort Study. Int. J. Periodontics Restor. Dent. 2017, 37, 781-788. [CrossRef] [PubMed]

44. Lerario, F.; Roncati, M.; Gariffo, A.; Attorresi, E.; Lucchese, A.; Galanakis, A.; Palaia, G.; Romeo, U. Non-surgical periodontal treatment of peri-implant diseases with the adjunctive use of diode laser: Preliminary clinical study. Lasers Med. Sci. 2016, 31, 1-6. [CrossRef] [PubMed]

45. Hegazy, S.; Elmekawy, N.; Emera, R.M. Peri-implant Outcomes with Laser vs Nanosurface Treatment of Early Loaded Implant-Retaining Mandibular Overdentures. Int. J. Oral Maxillofac. Implant. 2016, 31, 424-430. [CrossRef] [PubMed]

46. John, G.; Becker, J.; Schmucker, A.; Schwarz, F. Non-surgical treatment of peri-implant mucositis and peri-implantitis at two-piece zirconium implants: A clinical follow-up observation after up to 3 years. J. Clin. Periodontol. 2017, 44, 756-761. [CrossRef] [PubMed]

47. Valente, N.A.; Andreana, S. Treatment of Peri-implantitis Using a Combined Decontaminative and Regenerative Protocol: Case Report. Compend. Contin. Educ. Dent. 2018, 39, 96-101. [PubMed]

48. Romeo, U.; Nardi, G.M.; Libotte, F.; Sabatini, S.; Palaia, G.; Grassi, F.R. The Antimicrobial Photodynamic Therapy in the Treatment of Peri-Implantitis. Int. J. Dent. 2016, 2016, 7692387. [CrossRef] [PubMed]

49. Al Amri, M.D.; Kellesarian, S.V.; Ahmed, A.; Al-Kheraif, A.A.; Romanos, G.E.; Javed, F. Efficacy of periimplant mechanical debridement with and without adjunct antimicrobial photodynamic therapy in patients with type 2 diabetes mellitus. Photodiagnosis Photodyn. 2016, 14, 166-169. [CrossRef] [PubMed]

50. Abduljabbar, T.; Javed, F.; Kellesarian, S.V.; Vohra, F.; Romanos, G.E. Effect of Nd:YAG laser-assisted non-surgical mechanical debridement on clinical and radiographic peri-implant inflammatory parameters in patients with peri-implant disease. J. Photochem Photobiol B. 2017, 168, 16-19. [CrossRef] [PubMed]

51. Larsen, O.I.; Enersen, M.; Kristoffersen, A.K.; Wennerberg, A.; Bunæs, D.F.; Lie, S.A.; Leknes, K.N. Antimicrobial Effects of Three Different Treatment Modalities on Dental Implant Surfaces. J. Oral Implantol. 2017, 43, 429-436. [CrossRef]

52. Nicholson, D.; Blodgett, K.; Beaverton, O.R.; Braga, C.; Finkbeiner, L.; Fourrier, J.; George, J.; Gregg, R.; Honigman, A.; Houser, B.; et al. Pulsed Nd:YAG Laser Treatment for Failing Dental Implants Due to Peri-implantitis. Proc. SPIE 2014, 8929.

53. Spadari, F.; Bombeccari, G.P.; Bosotti, B.; Marino, R. Photodynamic therapy on peri-implantitis: Comparative effectiveness - an in vivo trial. Oral Dis. 2010, 16, 553.

54. Bombeccari, G.P.; Guzzi, G.; Gualini, F.; Gualini, S.; Santoro, F.; Spadari, F. Photodynamic therapy to treat periimplantitis. Implant. Dent. 2013, 22, 631-638. [CrossRef] [PubMed]

55. Chambrone, L.; Wang, H.L.; Romanos, G.E. Antimicrobial photodynamic therapy for the treatment of periodontitis and peri-implantitis: An American Academy of Periodontology best evidence review. J. Periodontol. 2018, 89, 783-803. [PubMed]

56. Esposito, M.; Grusovin, M.G.; Coulthard, P.; Worthington, H.V. The efficacy of interventions to treat peri-implantitis: A Cochrane systematic review of randomised controlled clinical trials. Eur. J. Oral Implant. 2008, 1, 111-125.

57. Ashnagar, S.; Nowzari, H.; Nokhbatolfoghahaei, H.; Yaghoub Zadeh, B.; Chiniforush, N.; Choukhachi Zadeh, N. Laser treatment of peri-implantitis: A literature review. J. Lasers Med. Sci. 2014, 5, 153-162.

58. Papadopoulos, C.A.; Vouros, I.; Menexes, G.; Konstantinidis, A. The utilization of a diode laser in the surgical treatment of peri-implantitis. A randomized clinical trial. Clin. Oral Investig. 2015, 19, 1851-1860. [CrossRef] 
59. Renvert, S.; Roos-Jansåker, A.M.; Claffey, N. Non-surgical treatment of peri-implant mucositis and peri-implantitis: A literature review. J. Clin. Periodontol. 2008, 35, 305-315. [CrossRef]

60. Renvert, S.; Lindahl, C.; Roos Jansåker, A.M.; Persson, G.R. Treatment of peri-implantitis using an Er:YAG laser or an air-abrasive device: A randomized clinical trial. J. Clin. Periodontol. 2011, 38, 65-73. [CrossRef]

61. Yan, M.; Liu, M.; Wang, M.; Yin, F.; Xia, H. The effects of Er:YAG on the treatment of peri-implantitis: A meta-analysis of randomized controlled trials. Lasers Med. Sci. 2015, 30, 1843-1853. [CrossRef]

62. Natto, Z.S.; Aladmawy, M.; Levi, P.A., Jr.; Wang, H.L. Comparison of the efficacy of different types of lasers for the treatment of peri-implantitis: A systematic review. Int. J. Oral Maxillofac. Implant. 2015, 30, 338-345. [CrossRef] [PubMed]

63. Smeets, R.; Henningsen, A.; Jung, O.; Heiland, M.; Hammächer, C.; Stein, J.M. Definition, etiology, prevention and treatment of peri-implantitis-a review. Head Face Med. 2014, 10, 34. [CrossRef] [PubMed]

64. Kotsakis, G.A.; Konstantinidis, I.; Karoussis, I.K.; Ma, X.; Chu, H. Systematic review and meta-analysis of the effect of various laser wavelengths in the treatment of peri-implantitis. J. Periodontol. 2014, 85, 1203-1213. [CrossRef] [PubMed]

65. Figuero, E.; Graziani, F.; Sanz, I.; Herrera, D.; Sanz, M. Management of peri-implant mucositis and peri-implantitis. Periodontol 2000, 66, 255-273. [CrossRef] [PubMed]

66. Suárez-López Del Amo, F.; Yu, S.H.; Wang, H.L. Non-Surgical Therapy for Peri-Implant Diseases: A Systematic Review. J. Oral Maxillofac. Res. 2016, 7, e13. [CrossRef] [PubMed]

67. Alshehri, F.A. The role of lasers in the treatment of peri-implant diseases: A review. Saudi Dent. J. 2016, 28, 103-108. [CrossRef] [PubMed]

68. Ghanem, A.; Pasumarthy, S.; Ranna, V.; Kellesarian, S.V.; Abduljabbar, T.; Vohra, F.; Malmstrom, H. Is mechanical curettage with adjunct photodynamic therapy more effective in the treatment of peri-implantitis than mechanical curettage alone? Photodiagnosis Photodyn. 2016, 15, 191-196. [CrossRef]

69. Mizutani, K.; Aoki, A.; Coluzzi, D.; Yukna, R.; Wang, C.Y.; Pavlic, V.; Izumi, Y. Lasers in minimally invasive periodontal and peri-implant therapy. Periodontol 2000, 71, 185-212. [CrossRef]

70. Mahato, N.; Wu, X.; Wang, L. Management of peri-implantitis: A systematic review, 2010-2015. Springerplus 2016, 5, 105. [CrossRef]

71. Al Habashneh, R.; Asa'ad, F.A.; Khader, Y. Photodynamic therapy in periodontal and peri-implant diseases. Quintessence Int. 2015, 46, 677-690.

72. Subramani, K.; Wismeijer, D. Decontamination of titanium implant surface and re-osseointegration to treat peri-implantitis: A literature review. Int. J. Oral Maxillofac. Implant. 2012, 27, 1043-1054.

73. Rajesh, S.; Koshi, E.; Philip, K.; Mohan, A. Antimicrobial photodynamic therapy: An overview. J. Indian Soc Periodontol. 2011, 15, 323-327. [PubMed]

74. Gonçalves, F.; Zanetti, A.L.; Zanetti, R.V.; Martelli, F.S.; Avila-Campos, M.J.; Tomazinho, L.F.; Granjeiro, J.M. Effectiveness of 980-mm diode and 1064-nm extra-long-pulse neodymium-doped yttrium aluminum garnet lasers in implant disinfection. Photomed Laser Surg. 2010, 28, 273-280. [CrossRef] [PubMed]

75. Kotsovilis, S.; Karoussis, I.K.; Trianti, M.; Fourmousis, I. Therapy of peri-implantitis: A systematic review. J. Clin. Periodontol. 2008, 35, 621-629. [CrossRef] [PubMed]

76. Dörtbudak, O.; Haas, R.; Bernhart, T.; Mailath-Pokorny, G. Lethal photosensitization for decontamination of implant surfaces in the treatment of peri-implantitis. Clin. Oral Implant. Res. 2001, 12, 104-108. [CrossRef]

77. Grzech-Leśniak, K.; Nowicka, J.; Pajączkowska, M.; Matys, J.; Szymonowicz, M.; Kuropka, P.; Rybak, Z.; Dobrzyński, M.; Dominiak, M. Effects of Nd:YAG laser irradiation on the growth of Candida albicans and Streptococcus mutans: In vitro study. Lasers Med. Sci. 2019, 34, 129-137. [CrossRef] [PubMed]

78. Matys, J.; Flieger, R.; Dominiak, M. Effect of diode lasers with wavelength of 445 and $980 \mathrm{~nm}$ on a temperature rise when uncovering implants for second stage surgery: An ex-vivo study in pigs. Dent. Med. Probl. 2017, 26, 687-693. [CrossRef]

79. Grzech-Leśniak, K.; Matys, J.; Dominiak, M. Comparison of the clinical and microbiological effects of antibiotic therapy in periodontal pockets following laser treatment: An in vivo study. Adv. Clin. Exp. Med. 2018, 27, 1263. [CrossRef]

(C) 2019 by the authors. Licensee MDPI, Basel, Switzerland. This article is an open access article distributed under the terms and conditions of the Creative Commons Attribution (CC BY) license (http://creativecommons.org/licenses/by/4.0/). 